\title{
Penerapan Model Pembelajaran Reading Questioning and Answering (RQA) di Masa Pandemi Covid-19 Untuk Meningkatkan Hasil Belajar Siswa Pada Mata Pelajaran Sistem Komputer Di SMK Negeri 7 Bulukumba
}

\author{
Tri Rahmat Tasa ${ }^{1}$, Sugeng A. Karim ${ }^{2}$, Riana T. Mangesa \\ Jurusan Teknik Informatika dan Komputer, Universitas Negeri Makassar \\ ${ }^{1}$ rahmattasaegmail.com \\ ${ }^{3}$ Rianamangesalyahoo.com
}

\begin{abstract}
Abstrak - Penelitian ini bertujuan untuk mengetahui peningkatan hasil belajar siswa melalui penerapan model pembelajaran $R Q A$ dan bagaimana respon siswa dalam penerapan model pembelajaran $R Q A$ siswa kelas X TKJ B di SMK Negeri 7 Bulukumba. Penelitian ini merupakan penelitian tindakan kelas yang terdiri atas empat tahapan yaitu perencanaan tindakan, pelaksanaan tindakan, evaluasi dan refleksi. Penelitian ini dilaksanakan dalam dua siklus, setiap s iklus terdiri atas dua kali pertemuan. Data dikumpulkan menggunakan teknik dokumentasi, angket, observasi, dan tes online melalui google form dan whatsapp. Teknik analisis data yang digunakan adalah analisis statistik deskriptif. Hasil penelitian menunjukkan bahwa penerapan model pembelajaran $R Q A$ dapat meningkatkan hasil belajar siswa kelas X TKJ B di SMK Negeri 7 Bulukumba. Oleh karena itu disarankan kepada pihak guru dan sekolah untuk menerapkan model pembelajaran $R Q A$ secara luas.
\end{abstract}

Kata Kunci: Reading Questioning and Answering, Hasil belajar, Sistem Komputer.

\section{PENDAHULUAN}

Pendidikan memiliki peranan yang sangat penting dalam menghasilkan sumber daya manusia (SDM) yang kompeten dan mampu bersaing dalam era globalisasi. Pesatnya pertumbuhan ilmu pengetahuan dan teknologi membawa pengaruh terhadap kemajuan suatu bangsa. Terdapat hubungan timbal-balik antara ilmu pengetahuan dan teknologi. Menurut Surajiyo (2010) menyatakan bahwa ilmu menyediakan bahan pendukung penting bagi kemajuan teknologi berupa teori-teori, sedangkan penemuan teknologi sangat membantu perluasan cakrawala penelitian ilmiah. Perkembangan teknologi mempunyai peranan penting dalam memberikan arah perkembangan bagi mutu pendidikan.

Mutu pendidikan sangat berpengaruh terhadap kualitas sumber daya manusia yang dihasilkan. Mutu pendidikan menurut Permendiknas nomor 63 tahun 2009 adalah tingkat kecerdasan kehidupan bangsa yang dapat diraih dari penerapan Sistem Pendidikan Nasional. Kualitas sumber daya manusia dapat dilihat dari kemampuan lulusannya yang memiliki keterampilan, menguasai teknologi, serta memiliki pengetahuan yang luas dan keahlian profesional. Satu di antara kebijakan pendidikan selain pemerataan kesempatan memperoleh pendidikan adalah meningkatkan kualitas dan relevansi guna meningkatkan daya saing keluaran pendidikan (lulusan). Masalah rendahnya kualitas pendidikan masih dirasakan sebagai permasalahan yang serius mulai dari pendidikan dasar hingga pendidikan tinggi.

Dalam mengatasi permasalahan tersebut, perlu memperhatikan faktor-faktor yang mempengaruhinya. Di antaranya dengan mengatasi masalah belajar siswa yang pada umumnya adalah sulit mempelajari konsep yang abstrak, sulit membayangkan peristiwa yang telah lalu, sulit mengamati obyek yang terlalu kecil atau terlalu besar, sulit memperoleh pengalaman langsung, sulit memahami pelajaran yang diceramahkan, sulit memahami konsep yang rumit, terbatasnya waktu untuk belajar. Selain itu sikap pasif dan kurangnya motivasi peserta didik juga menjadi faktor rendahnya mutu pendidikan.

Berdasarkan hal tersebut di atas, nampaknya peningkatan mutu pendidikan perlu diarahkan pada perluasan inovasi pembelajaran yang baik dalam rangka mewujudkan proses pembelajaran yang efisien, menyenangkan dan mencerdaskan sesuai tingkat usia, kematangan, serta tingkat perkembangan peserta didik. Namun, salah satu yang menjadi tantangan dalam peningkatan mutu pendidikan yaitu munculnya wabah corona virus disease 2019 (Covid-19). Dengan adanya virus Covid-19 pemerintah membuat beberapa kebijakan untuk menghentikan penyebaran wabah ini, seperti melakukan lockdown di daerah yang sudah termasuk ke dalam zona merah penyebaran virus, lalu physical quarantine untuk menghindari penyebaran virus secara kontak fisik.

Berdasarkan hal tersebut di atas, dapat diketahui bahwa pendidikan harus berjalan dalam keadaan apapun. Untuk mengurangi angka penyebaran Covid-19 dan kegiatan pendidikan dapat berjalan seperti biasanya maka pemerintah melakukan beberapa upaya untuk mengurangi angka tersebut yang salah satunya diterapkan dalam sistem pendidikan di Indonesia. Pelaksanaan kegiatan belajar mengajar dilaksanakan dengan sistem online atau sistem dalam jaringan (daring) sejak bulan Maret 2020. Sistem pembelajaran tersebut dilakukan tanpa tatap muka secara langsung, melainkan dilakukan dengan sistem pembelajaran jarak jauh.

Pembelajaran yang dilakukan selama ini masih sering menggunakan pembelajaran konvensional. Pembelajaran konvensional masih dilaksanakan atas asumsi bahwa suatu pengetahuan dapat dipindahkan secara utuh dari pikiran guru ke siswa sebagaimana yang disampaikan oleh (Djamarah1996). Model pembelajaran konvensional adalah model pembelajaran tradisional atau disebut juga dengan model ceramah, karena sejak dulu model ini telah dipergunakan sebagai alat komunikasi lisan antara guru dengan anak didik dalam proses belajar dan pembelajaran.

Salah satu upaya untuk meningkatkan hasil belajar peserta didik dengan menerapkan model pembelajaran Reading Questioning and Answering (RQA). Model pembelajaran RQA dapat meningkatkan kesadaran metakognitif, keterampilan metakognitif, dan hasil belajar kognitif peserta didik. Hal tersebut dikarenakan model pembelajara $R Q A$ merupakan model pembelajaran yang berpusat pada peserta didik dan menuntut 
peserta didik untuk aktif mempersiapkan dirinya sebelum pembelajaran. Model pembelajaran $R Q A$ memaksa peserta didik untuk membaca materi yang akan diajarkan, sehingga model pembelajaran yang dirancang dapat terlaksana dan pemahaman terhadap materi berhasil ditingkatkan. Keunggulan lainnya dalam model pembelajaran $R Q A$ adalah penugasan dalam membuat pertanyaan dan membuat jawaban. $R Q A$ merupakan model pembelajaran yang berlandaskan pada teori konstruktivisme (Hasanuddin,2013). Model pembelajaran ini dikembangkan atas kenyataan bahwa hampir semua siswa yang ditugaskan untuk membaca materi pelajaran pada pertemuan berikutnya selalu tidak dilakukan, hal ini berakibat rendahnya pemahaman siswa pada materi pelajaran tersebut. Implementasi model pembelajaran $R Q A$ terbukti mampu mendorong siswa untuk membaca materi pelajaran yang ditugaskan, sehingga model pebelajaran yang dirancang dapat terlaksana dengan baik dan pemahaman terhadap materi pembelajaran berhasil ditingkatkan.

Berdasarkan uraian di atas, penerapan model pembelajaran $R Q A$ diyakini dapat mendorong siswa rajin membaca materi yang ditugaskan, memahami isi bacaannya serta menemukan bagian yang terpenting dari hasil bacaannya tersebut.

Model pembelajaran $R Q A$ juga mampu meningkatkan keaktifan siswa dalam mengkonstruksi pengetahuannya sesuai dengan pengalaman belajar yang mereka dapatkan, serta mampu meningkatkan kemampuan berpikir awal siswa terhadap materi sehingga berdampak baik pada hasil belajar.

Model pembelajaran adalah seluruh perencanaan dan prosedur maupun langkah-langkah kegiatan pembelajaran termasuk pilihan cara penilaian yang akan dilaksanakan (Suyono dkk, 2011). Arti lain dari model pembelajaran adalah sebagai cara dalam pembelajaran yang dilakukan oleh guru dalam mengimplementasikan suatu model secara spesifik. Model-model dalam pembelajaran yaitu ceramah, tanya jawab, diskusi, demonstrasi, sosiodrama, bermain peran, simulasi, drill/latihan, tanya jawab, proyek problem solving, kooperatif, inkuiridiscovery, karya wisata.

SMK Negeri 7 Bulukumba merupakan salah satu Sekolah Menengah Kejuruan Negeri yang ada di Kabupaten Bulukumba. SMK Negeri 7 Bulukumba membina 3 kompetensi keahlian, yaitu: Nautika Kapal Penangkapan Ikan (NKPI), Teknik Kendaran Ringan (TKR), Teknik Komputer dan Jaringan (TKJ). Sejak didirikan pada tahun 2008 SMK Negeri 7 Makassar memperoleh Akreditasi B (Baik) dari Badan Akreditasi Nasional Sekolah/ Madrasah (BAN S/M).

Berdasarkan hasil wawancara yang dilakukan dengan ibu Sukma selaku ketua Jurusan Teknik Layanan dan Jaringan SMK Negeri 7 Bulukumba pada tanggal 21 September 2020, diperoleh informasi bahwa rata-rata hasil belajar siswa masih sangat rendah hanya sekitar $30 \%$ yang mencapai nilai KKM dan standar nilai KKM yaitu 75. Hal ini disebabkan karena minat belajar siswa yang masih sangat kurang, diperoleh pula informasi bahwa dalam proses pembelajaran di kelas X TKJ lebih banyak menggunakan metode ceramah sehingga guru lebih aktif dari pada siswa. Kebanyakan siswa kurang mengetahui cara belajar yang baik. Guru lebih menekankan siswa untuk menguasai isi materi pelajaran yang diajarkan, sehingga dalam proses pembelajaran berlangsung keterampilan siswa saat belajar masih sangat kurang. Siswa lebih banyak melakukan kegiatan pembelajaran dengan mencatat, mendengarkan penjelasan materi dan mengerjakan tugas yang diberikan oleh guru, oleh karena itu tidak terjadi umpan balik antara siswa dan guru ketika proses pembelajaran berlangsung. Siswa cenderung lebih banyak diam, tidak aktif, kemandirian, dan tanggung jawab siswa sangat kurang, ketika proses pembelajaran berlangsung. Padahal orientasi belajar bukan hanya penguasaan terhadap materi yang dipelajari, tetapi menekankan pada pemahaman terhadap proses serta keterampilan yang diperlukan untuk menguasai suatu materi. Penguasaan terhadap cara-cara belajar yang baik sebetulnya memberikan gambaran tentang kadar penguasaan siswa terhadap keterampilan belajar, karena dengan menguasai keterampilan belajar, siswa akan menyadari bagaimana cara belajar yang baik sehingga menjadi lebih bertanggungjawab terhadap cara belajarnya.

Berdasarkan hasil observasi yang dilakukan oleh peneliti di SMK Negeri 7 Bulukumba, peneliti mengkaji Penerapan Model Pembelajaran Reading Questioning and Answering (RQA) Di Masa Pandemi Covid-19 untuk Meningkatkan Hasil Belajar Siswa pada Mata pelajaran Sistem Komputer Di SMK Negeri 7 Bulukumba.

\section{MODEL PENELITIAN}

A. Jenis Penelitian

Jenis penelitian yang digunakan adalah penelitian tindakan kelas (classroom action research). Penelitian tindakan kelas adalah penelitian yang bersifat reflektif melalui tindakan tertentu yang bertujuan untuk meningkatkan praktik - praktik pembelajaran di kelas secara profesional. Tindakan yang dimaksud pada penelitian ini adalah penerapan model pembelajaran Reading Questioning and Answering (RQA). Masalah pembelajaran yang akan diselesaikan pada penelitian ini adalah rendahnya hasil belajar siswa kelas X Sistem Komputer di SMK Negeri 7 Bulukumba.

\section{B. Setting Penelitian}

a. Waktu penelitian

Penelitian ini dilaksanakan sejak tanggal dikeluarkannya izin penelitian dalam kurun waktu kurang lebih dua bulan, yaitu bulan Januari - Februari 2021. Satu bulan untuk pengumpulan data dan satu bulan untuk pengolahan data yang meliputi penyajian dalam bentuk hasil penelitian dan proses bimbingan berlangsung.

b. Tempat penelitian

Penelitian ini akan dilaksanakan di SMK Negeri 7 Bulukumba yang beralamat Jl.Karaeng Cidu Dg. Matarang, Tanah Jaya, Kec. Kajang, Kab. Bulukumba, Sulawesi Selatan.

c. Subjek penelitian

Subjek pada penelitian ini adalah siswa kelas X Sistem Komputer dengan karakteristik yang beragam (heterogen). Subjek penelitian berjumlah 26 orang siswa dengan karakteristik sebagaimana ditunjukkan pada tabel berikut.

Tabel 1. Subjek penelitian berdasarkan jenis kelamin

\begin{tabular}{|c|c|c|}
\hline No & Jenis kelamin & Jumlah \\
\hline 1 & Laki - laki & 6 \\
\hline 2 & Perempuan & 20 \\
\hline \multicolumn{2}{|c|}{ Jumlah } & 26 \\
\hline
\end{tabular}

Tabel 2. karakteristik siswa berdasarkan indikator keberhasilan

\begin{tabular}{|c|c|c|}
\hline No & $\begin{array}{c}\text { Indikator } \\
\text { Keberhasilan }\end{array}$ & Keterangan \\
\hline 1 & $>75$ & Tuntas \\
\hline 2 & $<75$ & Tidak tuntas \\
\hline
\end{tabular}

C. Desain Penelitian

Prosedur tindakan pada penelitian ini menggunakan prosedur penelitian tindakan MC Taggart. pembelajaran Prosedur jalannya penelitian tindakan kelas disajikan pada Gambar 1. 


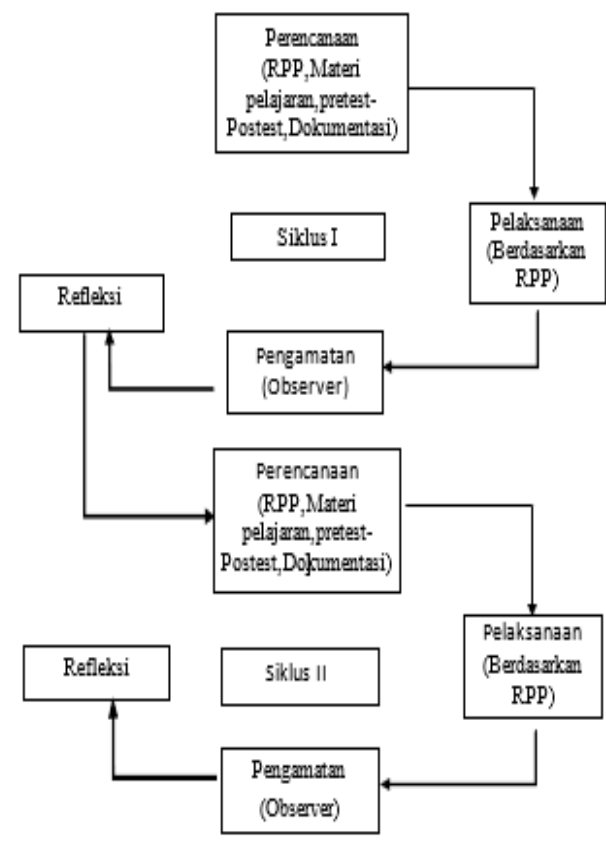

Gambar 1. Prosedur Penelitian Tindakan Kelas

D. Defenisi Operasional Variabel

Defenisi operasional variabel sebagai berikut :

1. Model pembelajaran $R Q A(\mathrm{X})$ merupakan Pembelajaran yang mengharuskan siswa untuk aktif dalam proses pembelajaran guna dapat meningkatkan hasil belajar siswa kelas X TKJ SMK Negeri 7 Bulukumba terhadap pelajaran Sistem Komputer.

2. Hasil belajar (Y) adalah kemampuan-kemampuan yang dimiliki siswa kelas X TKJ SMK Negeri 7 Bulukumba setelah menerima pengalaman belajarnya. Tingkat hasil belajar siswa kelas X TKJ SMK Negeri 7 Bulukumba diukur dengan menggunakan instrument test, untuk membandingkan antara hasil pretest dan posttest.

E. Teknik dan Instrumen pengumpulan data

1. Teknik Pengumpulan Data

Teknik yang digunakan untuk memperoleh data dalam penelitian ini adalah sebagai berikut:

a) Tes

Tes digunakan untuk mengetahui hasil akhir belajar siswa yaitu berupa pretest dan post test

b) Observasi

Observasi digunakan sebagai teknik yang ditujukan untuk mempelajari perilaku siswa, proses kerja, dan dilakukan pada responden yang tidak terlalu besar.

c) Angket

Angket adalah teknik pengumpulan data yang dilakukan dengan cara memberi seperangkat pertanyaan tertulis kepada responden untuk dijawabnya, dapat diberikan secara langsung atau melalui pos atau internet.

d) Dokumentasi.

Dokumentasi digunakan sebagai data penunjang dalam penelitian ini, meliputi data jumlah siswa, gambar kegiatan dan lain sebagainya.

2. Instrumen Penelitian

Instrumen penelitian digunakan sebagai alat bantu yang dipilih dan digunakan oleh peneliti dalam kegiatan mengumpulkan, agar kegiatan tersebut menjadi sistematis, kemudian jenis instrumen penelitian sendiri yaitu observasi, angket atau daftar centang, pretest dan posttes dan dokumentasi.

\section{HASIL DAN PEMBAHASAN}

\section{A. Hasil Penelitian}

1. Siklus I

a. Perencanaan (Planning)

Beberapa persiapan yang diperlukan untuk melaksanakan siklus I antara lain:

1) Membuat skenario pembelajaran atau Rencana Pelaksanaan Pembelajaran (RPP) dengan model pembelajaran $R Q A$.

2) Mempersiapkan materi dan media yang akan disampaikan dalam pembelajaran Sistem Komputer.

3) Mempersiapkan soal evaluasi (pretest dan postest).

4) Menyiapkan peralatan-peralatan untuk mendokumentasikan kegiatan selama proses pembelajaran berlangsung.

b. Tindakan (action)

Siklus I dilakukan sejak bulan Januari 2021 dengan menggunakan RPP yang telah dibuat. Pada Siklus I dilaksanakan selama dua kali pertemuan. Dalam penelitian ini selama pembelajaran berlangsung, guru melakukan kegiatan pembelajaran sesuai RPP yang meliputi kegiatan pendahuluan, kegiatan inti dan kegiatan penutup.

c. Observasi

Pada setiap pertemuan, pengamatan dilakukan sejak awal sampai akhir pembelajaran menggunakan lembar observasi. Hasil observasi selama pelaksanaan tahap I adalah sebagai berikut :

1) Perangkat pembelajaran yang digunakan selama proses pembelajaran telah disiapkan peneliti

2) Guru telah menggali pengetahuan siswa tentang pengertian organisasi komputer.

3) Siswa mengemukakan pengetahuannya tentang hal yang berkaitan dengan materi pengertian organisasi computer

4) Guru dan peneliti mengarahkan siswa untuk membuat pertanyaan dan menjawab pertanyaan sendiri.

5) Secara keseluruhan, keaktifan siswa masih belum tampak. Hal ini terbukti dari 26 siswa hanya 14 siswa yang membuat pertanyaan dan menjawab pertanyaan sedniri. Untuk yang lain masih terlihat pasif, cenderung berdiam diri saat pelajaran berlangsung.

6) Dalam menyampaikan idenya siswa masih ragu-ragu dan jika menyampaikan pendapatnya dengan suara sangat pelan.

7) Proses pembelajaran masih belum berjalan dengan baik, dimana guru mengalami mengkondisikan siswa yang masih tampak gaduh dan siswa yang mematikan kamera saat proses pembelajaran berlangsung di google meet.

d. Refleksi

Pada siklus pertama menunjukkan bahwa siswa telah mampu memahami materi adalah pengertian dan perbedaan organisasi dan arsitektur komputer, namun masih terdapat siswa yang belum sesuai dengan yang diharapkan. Selama tindakan pada siklus pertama berlangsung peneliti melakukan pengamatan serta menganalisa hasil pembelajaran Sistem Komputer tentang materi perangkat pengolah kata dan angka.

Berdasarkan hasil yang diperoleh pada akhir pembelajaran dapat ditarik kesimpulan sebagai refleksi yakni guru dalam pembelajaran Sistem Komputer dengan menggunakan model pembelajaran Reading Questioning and Answering (RQA) dalam pembelajaran materi struktur dan fungsi utama komputer. Akan tetapi pada siklus I masih terdapat kendala karena proses belajar mengajar yang dilakukan secara daring (kelas online) sarana yang menunjang pembelajaran online yang kurang memadai, siswa kurang menyimak slide presentasi pembelajaran, tidak berani bertanya jika ada materi yang tidak diketahui. Berbagai kekurangan dalam proses pembelajaran pada siklus I akan dilanjutkan pada 
siklus ke II, agar pembelajaran berlangsung secara maksimal. Guru telah menggunakan model pembelajaran $R Q A$ karena berlangsung secara perorangan besar menyebabkan aktivitas siswa dalam pembelajaran kurang terkontrol. Oleh karena itu praktis tindakan siklus I dilanjutkan ke siklus ke II agar pembelajaran berlangsung secara optimal.

1) Analisis Hasil Tes

Tabel 3. Analisis Hasil Pretest dan Postest Siklus I

\begin{tabular}{|l|c|c|c|c|}
\hline Keterangan & Penilaian & $\begin{array}{c}\text { Siswa } \\
\text { tuntas }\end{array}$ & $\begin{array}{c}\text { Siswa } \\
\text { tidak } \\
\text { tuntas }\end{array}$ & $\begin{array}{c}\text { Persentase } \\
\text { siswa } \\
\text { tuntas }\end{array}$ \\
\hline Pertemuan I & Pretest & 5 & 21 & $19 \%$ \\
\hline Pertemuan II & Postest & 10 & 16 & $38 \%$ \\
\hline
\end{tabular}

Berdasarkan analisis hasil pretest dan postest yang telah dilakukan dengan bukti data yang dilihat pada lampiran III distribusi data, tampak bahwa dari 26 siswa hanya 5 siswa yang dapat dinyatakan tuntas, Sedangkan 21 siswa belum dapat dinyatakan tuntas (memperoleh nilai di bawah 75). Selanjutnya analisis hasil Postest yang dilakukan pada pertemuan ke-2, tampak bahwa yang tuntas sudah mengalami peningkatan yaitu 10 siswa dinyatakan lulus, sedangkan 16 siswa belum dinyatakan tuntas atau masih dibawah nilai yang telah ditentukan. Dari data tersebut, dapat diketahui bahwa ketuntasan klasikal pada pretest hanya sebesar $19 \%$ dengan nilai rata-rata (Mean) yaitu 41,9 dan ketuntasan klasikal pada Postest sebesar 38\% dengan nilai rata-rata (Mean) yaitu 64.6.

2. Siklus II

a. Perencanaan (Planning)

Beberapa persiapan yang diperlukan untuk melaksanakan siklus II antara lain :

1) Membuat skenario pembelajaran atau Rencana Pelaksanaan Pembelajaran (RPP) dengan model pembelajaran Reading Questioning and Answering (RQA)

2) Mempersiapkan materi dan media yang akan disampaikan dalam pembelajaran Sistem Komputer.

3) Mempersiapkan LKPD soal evaluasi (pretest dan postest) melalui whatsapp.

4) Menyiapkan peralatan-peralatan untuk mendokumentasikan kegiatan selama proses pembelajaran berlangsung

b. Tindakan (action)

Siklus II dilakukan sejak bulan Februari 2021. Pada Siklus II dilaksanakan selama 2 kali pertemuan. Tindakan siklus II pada prinsipnya sama dengan siklus I. Perencanaan tindakan siklus II dilakukan dengan berbagai perbaikan dalam proses pembelajaran yang mengacu pada siklus sebelumnya. Perencanaan dalam tindakan siklus II ini adalah guru mengadakan perbaikan berdasarkan hasil siklus I agar proses pembelajaran lebih optimal dalam pelaksanaan kegiatan pembelajaran.

Materi yang diberikan pada siklus II adalah Struktur dan Fungsi Utama Komputer. Strategi pembelajaran yang digunakan masih sama seperti siklus I, yaitu model pembelajaran $R Q A$. Pelaksanaan kegiatan pembelajaran pada siklus II menggunakan instrumen penelitian berupa silabus mata pelajaran Sistem Komputer, RPP, angket siswa, tes (posttest) dan observasi

c. Observasi

Hasil observasi selama kegiatan pada Tahap II adalah sebagai berikut.

1) Perangkat pembelajaran yang digunakan dalam kegiatan pembelajaran telah dipersiapkan dengan baik.

2) Guru telah menggali pengetahuan siswa dengan mengajukan pertanyaan tentang materi yang diajarkan.
3) Guru dan peneliti membimbing diskusi, baik diskusi kelompok maupun diskusi kelas.

4) Siswa telah mengemukakan pendapatnya yang berhubungan dengan materi.

5) Kerjasama dan keaktivan siswa sudah mulai tampak, hal ini terbukti darisikap siswa yang menunjukkan rasa ingin tahu dengan mengajukan pertanyaan kepada peneliti maupun kepada teman .

6) Sebagian besar siswa sudah mulai berani mengungkapkan dan menjawab pertanyaan. Di tahap II ini, masih ada satu kelompok yaitu kelompok IV yang menurut observer masih banyak berdiam diri saat diskusi berlangsung.

7) Ketertiban juga sudah tampak terutama saat transisi dari siswa yang tergolong berkemampuan rendah menjadi lebih aktif, demikian juga saat diskusi berlangsung sudah tidak banyak ditemukan lagi kegaduhan.

d. Refleksi

Peneliti melihat siklus ke dua menunjukkan keberhasilan yang cukup positif, efektif, dan maksimal dalam pembelajaran. Hasil belajar siswa telah sesuai dengan yang diharapkan karena pada siklus ke dua proses pembelajaran dilakukan lebih efektif karena sebelum pembelajaran di mulai siswa diberikan motivasi agar lebih bisa memperhatikan penjelasan guru selama proses pembelajaran berlangsung, terpantaunya proses diskusi tiap - tiap kelompok, juga denga adanya pemberian reward kepada siswa yang mendapatkan nilai tertinggi menambah motivasi siswa untuk lebih bersemangat memperhatikan pembelajaran dan mengerjakan soal evaluasi. Selama tindakan pada siklus ke dua peneliti melakukan pengamatan serta menganalisa hasil pembelajaran Sistem Komputer. Berdasarkan hasil yang diperoleh pada akhir pembelajaran yang dilaksanakan peneliti sudah berlangsung secara maksimal. Peneliti menggunakan model pembelajaran $R Q A$ pada pellajaran Sistem Komputer, menunjukkan keberhasilan karena pembelajaran berlangsung secara efektif dan hasil belajar siswa maksimal. Adapun kelebihan model pembelajaran ini adalah pada dasarnya model pembelajaran $R Q A$ merupakan cara untuk menjadikan siswa aktif secara individu. Kegiatan pembelajaran akan kurang menarik jika siswa aktif secara individu, maka dibutukan model pembelajaran lain yang dapat menjadikan siswa aktif secara berkelompok agar siswa saling berbagi informasi dan pembelajaran dapat berjalan optimal dengan suasana yang menyenangkan.

1) Analisis Hasil Tes

Tabel 4. Analisis Hasil pretest dan Postest Siklus II

\begin{tabular}{|l|l|c|c|c|}
\hline No. & Penilaian & $\begin{array}{c}\text { Siswa } \\
\text { tuntas }\end{array}$ & $\begin{array}{c}\text { Siswa tidak } \\
\text { tuntas }\end{array}$ & $\begin{array}{c}\text { Persentase } \\
\text { Siswa Tuntas }\end{array}$ \\
\hline 1. & Pretest & 17 & 9 & $65 \%$ \\
\hline 2. & Postest & 23 & 3 & $88 \%$ \\
\hline
\end{tabular}

Berdasarkan analisis hasil pretest yang telah dilakukan dengan bukti data yang dilihat pada lampiran III distribusi data, tampak bahwa dari 26 siswa hanya 17 siswa yang dapat dinyatakan tuntas, Sedangkan 9 siswa belum dapat dinyatakan tuntas (memperoleh nilai di bawah 75). Sedangkan berdasarkan hasil postest yang telah dilakukan, tampak bahwa dari 26 siswa kini mengalami peningkatan sebanyak 23 siswa dapat dinyatakan tuntas, Sedangkan 3 siswa belum dapat dinyatakan tuntas (memperoleh nilai di bawah 75). Dari data tersebut, dapat diketahui bahwa ketuntasan klasikal pada pretest hanya sebesar $65 \%$ dengan nilai rata-rata (Mean) yaitu 68,8 dan ketuntasan klasikal pada Postest ini meningkat sebesar $88 \%$ dengan nilai rata-rata (Mean) yaitu 90.7 
dengan ini dapat disimpulkan bahwa ketuntasan hasil belajar pada Siklus II telah mencapai Kriteria Ketuntasan Minimal (KKM) yaitu 75 dan presentase klasikal (88\%). Data dari hasil Postest I dan II dapat dilihat pada lampiran 5 .

Berdasarkan paparan diatas, upaya peningkatan hasil belajar siswa pada siklus II menunjukkan hasil yang baik. Hasil belajar siswa kelas X TKJ B mengalami peningkatan. Oleh karena itu, pada Siklus II hasil belajar siswa lebih baik dari Siklus I. Ini menunjukkan bahwa penerapan model pembelajaran $R Q A$ dapat meningkatkan hasil belajar siswa. Tercapainya indikator keberhasilan penelitian menunjukkan bahwa penelitian tindakan kelas ini dapat diakhiri dengan dua Siklus. Peningkatan hasil belajar siswa dari Siklus I sampai Siklus II dapat ditunjukkan pada tabel dan diagram berikut:

Tabel 5. Rekapitulasi Peningkatan Hasil Belajar Siklus I dan Siklus II

\begin{tabular}{|c|c|c|c|c|}
\hline Siklus & $\begin{array}{c}\text { Jumlah } \\
\text { Siswa }\end{array}$ & $\begin{array}{c}\text { Jumlah } \\
\text { Siswa } \\
\text { Tuntas }\end{array}$ & Persentase & $\begin{array}{c}\text { Besar } \\
\text { Peningkatan } \\
\text { Yang } \\
\text { Terjadi }\end{array}$ \\
\hline Siklus I & 26 & 10 & $38 \%$ & \multirow{2}{*}{$32 \%$} \\
\hline Siklus II & 26 & 23 & $88 \%$ & \\
\hline
\end{tabular}

\section{B. Pembahasan}

1. Untuk mengetahui peningkatan hasil belajar siswa pada mata pelajaran sistem komputer melalui penerapan model pembelajara $R Q A$.

Berdasarkan hasil penelitian dengan menggunakan model pembelajaran $R Q A$ dilaksanakan dengan tindakan dua siklus yaitu Siklus I dan berakhir di Siklus II. Penelitian berakhir ditindakan Siklus II karena pada tindakan ini telah mencapai Indikator keberhasilan. Pada awal penelitian dilakukan Pretest untuk mengetahui pengetahuan awal belajar siswa pada pokok pembahasan perangkat pengolah kata dan angka serta fitur fitur perangkat pengolah kata dan angka.

Dilihat dari hasil Pretest yang telah dilakukan masih banyak siswa yang tidak tuntas, untuk itu perlu penerapan model pembelajaran yang lebih menarik agar siswa lebih aktif dalam proses pembelajaran serta hasil belajar siswa dapat meningkat. Pada tindakan Siklus I setelah pemberian materi, dilakukan tes evaluasi dengan pokok pembahasan yang sama.

Hasil evaluasi tindakan Siklus I jumlah siswa yang tuntas meningkat dari 19\% hasil Pretest menjadi 38\% hasil posttest, tetapi hal tersebut belum memenuhi indikator keberhasilan sesuai dengan yang ditetapkan. Hal ini sejalan dengan pendapat Sudjana (2004) tentang hasil belajar, bahwa hasil belajar sebagai objek penilaian pada hakikatnya menilai penguasaan siswa terhadap tujuan-tujuan instruksional, karena isi rumusan tujuan instruksional menggambarkan hasil belajar yang harus dikuasai siswa berupa kemampuan-kemampuan siswa setelah menerima atau menyelesaikan pengalaman belajarnya. Oleh kerena itu perlu dilanjutkan tindakan Siklus II untuk meningkatkan hasil belajar siswa dan mengurangi nilai siswa yang tidak tuntas, untuk memenuhi indikator keberhasilan yang ditetapkan. Dari hasil evaluasi tindakan Siklus II jumlah siswa yang tuntas meningkat dari 65\% hasil Pretest menjadi $88 \%$ hasil posttest. Perbandingan hasil belajar siswa pada Siklus I dan Siklus II sesuai rekapitulasi peningkatan hasil belajar dari Siklus I sebesar 38\% meningkat pada Siklus II menjadi 88\% Sehingga peningkatan dari Siklus I ke Siklus II adalah $32 \%$. Model pembelajaran $R Q A$ dapat meningkatkan hasil belajar siswa karena dengan penerapan model pembelajaran $R Q A$ pembelajaran di kelas lebih menyenangkan sehingga menarik perhatian siswa, dan khususnya siswa kelas X TKJ B.

Berdasarkan hasil evaluasi selama tindakan Siklus I dan Siklus II dapat dilihat hasil belajar siswa mengalami peningkatan setelah penerapan model pembelajaran Reading Questioning and
Answering (RQA).

2. Untuk mengetahui bagaimana respon siswa pada mata pelajaran sistem komputer melalui penerapan model pembelajaran $R Q A$.

Penerapan model pembelajaran reading questioning and answering (RQA) di masa pandemi covid-19 untuk meningkatkan hasil belajar siswa pada mata pelajaran sistem komputer di SMK Negeri 7 Bulukumba ini menggunakan jenis penelitian deskriptif, data diolah menggunakan SPSS 25 for windows, dengan subjek sebanyak 26 orang siswa. Pengumpulan data ini menggunakan angket yang diberikan kepada siswa untuk mengetahui respon siswa terhadap penerapan model $R Q A$. Berdasarkan hasil olah data yang dilakukan diperoleh bahwa untuk metode pembelajaran $R Q A$ dalam menjngkatkan hasil belajar siswa berada pada kategori baik dengan jumlah sebanyak 14 orang siswa, sedangkan untuk kategori sangat baik sebanyak 11 orang siswa dan kategori sangat tidak baik sebanyak 1 orang siswa.

Berdsarkan hasil olah data yang dilakukan peneliti dapat disimpulkan bahwa untuk mengetahui respon siswa melalui penerapan metode pembelajaran $R Q A$ dapat meningkatkan respon siswa pada mata pelajaran sistem komputer kelas X TKJ B.

\section{A. Kesimpulan}

\section{KESIMPULAN \& SARAN}

Berdasarkan dari hasil penelitian dan pembahasan yang telah dilakukan dapat disimpulkan bahwa:

1. Setelah penerapan model pembelajaran Reading Questioning and Answering RQA dapat meningkatkan hasil belajar siswa pada mata pelajaran Sistem Komputer kelas X TKJ B di SMKN 7 Bulukumba. Pembelajaran yang dilakukan dengan Ipenerapan model pembelajaran Reading Questioning and Answering (RQA) pada mata pelajaran Sistem Komputer terdiri yaitu, membaca materi (reading), membuat pertanyaan (questioning), menjawab pertanyaan (answering), melakukan diskusi, serta membuat kesimpulan.

2. Respon siswa terhadap penerapan model pembelajaran $R Q A$ di kelas X TKJ B di SMKN 7 Bulukumba pada mata pelajaran Sistem Komputer. Berdasarkan pengumpulan data menggunakan angket yang diberikan kepada siswa untuk mengetahui respon siswa terhadap penerapan model $R Q A$ diperoleh bahwa siswa berada pada kategori baik dengan jumlah sebanyak 14 orang siswa, sedangkan untuk kategori sangat baik sebanyak 11 orang siswa dan kategori sangat tidak baik sebanyak 1 orang siswa.

\section{B. Saran}

Berdasarkan hasil pembahasan dan kesimpulan, berikut disampaikan beberapa saran yang dapat dijadikan bahan pertimbangan dalam rangka perbaikan keterampilan belajar siswa ke arah yang lebih baik, yaitu:

1. Bagi sekolah

Hendaknya mengupayakan untuk memberikan fasilitas yang lebih dan menciptakan lingkungan belajar yang nyaman demi menunjang proses belajar dan prestasi belajar siswa mata pelajaran Sistem Komputer.

2. Bagi guru

a. Dengan adanya penelitian ini, melihat hasil-hasil yang diperoleh melalui pelaksanaan model pembelajaran $R Q A$, maka diharapkan kepada guru- guru khususnya guru SMKN 7 Bulukumba dapat mempertimbangkan strategi ini dalam upaya peningkatan hasil belajar siswa.

b. Dalam melaksanakan pembelajaran, guru sebaiknya menggunakan metode dan pendekatan yang bervariasi agar siswa tidak bosan atau jenuh sehingga berdampak pada hasil belajar siswa yang lebih baik. 
3. Bagi siswa

a. Siswa diharapkan dapat memberi dukungan penuh terhadap guru untuk mengembangkan berbagai variasi metode dan pendekatan pembelajaran yang diterapkan di dalam kelas.

b. Siswa perlu meningkatkan kemampuan belajarnya terutama dalam menghadapi kesulitan, bekerja kelompok, mencari dan memecahkan masalah pada soal-soal serta melaksanakan tugas-tugas yang diberikan oleh guru.

4. Bagi peneliti selanjutnya dapat mengembangkan model pembelajaran $R Q A$ yang lebih menarik agar mampu menghasilkan penelitian yang relevan

\section{DAFTAR PUSTAKA}

[1] Bahri Arsad. 2016. Potensi Strategi Problem Based Learning (PBL) Terintegrasi Reading Questioning and Answering (RQA) Untuk Meningkatkan Hasil Belajar Kognitif Mahasiswa. Malang: PPS Universitas Negeri Malang.

[2] Dimyati \& Mudjiono. 2006. Belajar dan Pembelajaran. Jakarta: PT Rineke Cipta

[3] Hamalik \& Oemar. 2009. Kurikulum dan Pembelajaran. Jakarta: Bumi Aksara.

[4] PT.Bumi Aksara.

[5] Hamdayama \& Jumanta. 2016. Metodologi Pengajaran. Jakarta: Bumi Aksara

[6] Hasanuddin. 2012. Implementasi Pembelajaran RQADipadu TPS Melalui Lesson Study Terhadap HasilBelajar Mahasiswa. Banda Aceh: PendidikanBiologi FKIP Universitas SyiahKuala.

[7] Johar, dkk. 2016. Strategi Belajar Mengajar. Yogyakarta: Deepublish.

[8] Kindy \& Nurul. 2015. Perbandingan Model Pembelajaran Jigsawdengan Group Investigation Untuk Meningkatkan Hasil Belajar Peserta didik Pada Sub Konsep Sistem Indera. Skripsi pada S.Pd Unpas Bandung:.

[9] Kusumah. 2011. Penelitian Tindakan Kelas. Jakarta: Indeks

[10] Maulida Fitri. 2016. Penerapan Strategi Pembelajaran Reading Questioning and Answering (RQA) Untuk Meningkatkan Hasil Belajar Siswa. Program Studi Pendidikan Fisika, Fakultas Keguruan dan Ilmu Pendidikan, Universitas Syiah Kuala.

[11] Maulida, dkk. 2016. Penerapan Strategi Pembelajaran Reading Questioning And Answering (RQA) Untuk Meningkatkan Hasil Belajar Siswa. Jurnal Ilmiah Mahasiswa Pendidikan Fisika

[12] Munandar \& Utami. 2009. Pengembangan kreativitas anak berbakat. Jakarta: Rineka cipta. 